\title{
Effect of Methodology on the Determination of Total Volatile Basic Nitrogen as an Index of Quality of Meat and Fish
}

\section{Omayma, M. Al - Taher Labib Maghraby*, Hassouba, M. M. and Eman, Ebrahim El-Mossalami}

Food hygiene Department, Animal Health Research Institute, Agriculture Research Center, Ministry of Agriculture, Egypt.

\section{KEYWORDS:}

Total volatile base nitrogen (TVB-N),

Dimethylamine (DMA),

Trimethylamine

(TMA), Trimethylamine

oxide

(TMAO),

Conway's

Microdiffusion Method,

Direct water vapor distillation method, water vapor distillation of an acidic extract.

\begin{abstract}
Determination of TVB-N values expressed as $\mathrm{mg} / 100 \mathrm{~g}$ of fresh meat and fish using four different methods (Conway s Microdiffusion; Direct water vapor distillation with $\mathrm{MgO}$; water vapour distillation of an acidic extract using Perchloric acid 6\% and vapour distillation of an acidic extract using trichloroacetic acid $7.5 \%$ ) were evaluated during storage in refrigerator till the beginning of spoilage. The results revealed that there was an increase in the level of TVB-N during storage of fresh meat from $4.03 \pm 0.152,6.72 \pm 0.37,6.18 \pm 4.59$ and $6.62 \pm 0.7$ at $1^{\text {st }}$ day to $43 \pm 0.31$, $50.08 \pm 0.5,47.1 \pm 0.32$ and $47.8 \pm 0.33$ at 11 th day, respectively and the mean values of TVB-N $\mathrm{mg} / 100 \mathrm{~g}$ of fresh fish were $5.03 \pm 1.12$, $7.71 \pm 0.58,7.14 \pm 0.47$ and $6.42 \pm 0.43$ to $66.5 \pm 0.39,73 \pm 0.1,70.67 \pm 1.48$ and $70.2 \pm 1.04$ respectively. Direct water vapor distillation with $\mathrm{MgO}$ yielded the highest concentration of TVB-N, whereas the lowest TVB-N value was obtained with the Conways Microdiffusion method. The accuracy $\%$ of detection of nitrogen in $\mathrm{mg} / 100 \mathrm{~g}$ from $100 \mathrm{ml}$ standard solution contained $210.9 \mathrm{mg}$ nitrogen using the four methods were 64.84, $69.43,99.81$ and 100.73 respectively.
\end{abstract}

*Corresponding author:

Introduction

Mobile: +2 01001049859

E-mail address: oma_magh@yahoo.com

Egyptian Journal of Food Safety

ISSN: 2314-5676 @ 2012 issued by Egyptian Veterinary Association for Food Control and Consumer Protection.

Peer review under responsibility of Egyptian Veterinary Association for Food Control and Consumer Protection
Volatile amines are the characteristic molecules responsible for the fishy odor and flavor present in fish several days after the catch and they are commonly used as criteria for assessing the fish quality. The determination of TVB-N known as to be the most common chemical parameter applied to evaluate the quality of fish and other meat products. TVB-N, being a measure of all the 
volatile nitrogen-containing compounds present in samples via steam distillation (Chan et al., 2006). Total Volatile Base Nitrogen (TVB-N) is one of the most widely used methods today to estimate the degree of decomposition of fish. It includes the measurement of trimethylamine (produced by spoilage bacteria), dimethylamine (produced by autolytic enzymes during frozen storage), ammonia (produced by the deamination of amino-acids and nucleotide catabolites) and other volatile nitrogenous compounds associated with seafood spoilage (Malle and Poumeyrol, 1989 and Riquixo, 1998). DMA and TMA results of the degradation of TMAO, a fish typical molecule which has an important role in osmoregulation, DMA is mostly produced by endogenous enzymes and TMA by bacterial enzymes (Huss, 1995; Etienne, 2005 and Chebet Lillian, 2007).

Ali et al., (2010) reported that the Spoilage was the result of whole series of complicated deteriorative changes brought about in dead fish tissue by its own enzyme, by bacteria and by chemical action (Shewan, 1976). The early reaction of spoilage is autolytic and bacterial enzymes become progressively the more active in the later stages (Jones, 1954). After catching the fish, the oxygen supply in the tissue ceases due to disruption of the circulatory system. In short time of postmortem, the mitochondrial system ceases to function. Adenosine triphosphate (ATP) is gradually depleted through the action of various ATPase. After residual supplies of creatine phosphate have been depleted, anaerobic glycolysis continue to regenerate some ATP with the end product, lactate accumulation (Foegeding et al., 1996). Due to formation of lactic acid from glycogen by a series of enzymatic reaction in the tissue which decrease $\mathrm{pH}$ value. When the $\mathrm{pH}$ reaches a critical value, the ultimate $\mathrm{pH}$, certain critical enzymes, especially phosphorfructokinase, are inhibited and glycolysis ceases. A drop in the $\mathrm{pH}$ of the muscle triggers the release of proteolytic enzymes such as cathepsin. Enzymes from spoilage microorganisms can metabolize the amino acids of the fish muscle producing a wide variety of volatile compounds resulting off-flavors and odors. The combined total amount of ammonia (NH3), dimethylamine (DMA) and trimethylamine (TMA) in fish is called the total volatile base (TVB) nitrogen content of the fish and is commonly used as an estimate of spoilage. Total volatile nitrogen has been widely used as an index for freshness of fish. The increase in the amount of TVB parallel with the increase in TMA during spoilage. As the activity of spoilage bacteria increases after the death of a fish, a subsequent increase in the reduction of TMAO to TMA (Stansby et al., 1944).

Etienne, (2005) reported that The total volatile base nitrogen or total volatile bases noted TVB-N or TVB or TVN consists mainly of a mixture of ammonia, DMA and TMA plus amines from the decarboxylation of amino acids and other nitrogen compounds that become volatile when made alkaline, and the results of analysis are given in nitrogen equivalent, ammonia-N, DMA-N, TMA-N and TVB-N. The designation "volatile amines" regroups mostly three molecules, ammonia, dimethylamine (DMA) and trimethylamine (TMA). Also they reported that TVB-N is an indicator of spoilage of some fish species such as red fish, flat fish, gadoids, hake and Atlantic salmon. However TVB-N cannot be used as a freshness indicator (constant level during the first days of iced storage) and does not reflect the mode of spoilage. Huss, (1995) reported that the ammonia is formed by the bacterial degradation/deamination of proteins, peptides and amino-acids. It is also produced in the autolytic breakdown of adenosine monophosphate (AMP) in chilled seafood products. Although ammonia has been identified as a volatile component in a variety of spoiling fish, few studies have actually reported the quantification of this compound since it was impossible to determine its relative contribution to the overall increase in total volatile bases. Chebet Lillian, (2007) said that the determination of TVB-N in fish flesh can be measured by steam distillation of fish extract with subsequent titration against a strong acid, such as sulphuric acid $\left(\mathrm{H}_{2} \mathrm{SO}_{4}\right)$. However, according to Huss (1995) TVB-N 
concentrations may be affected by the mode of handling during the analysis, and they are often destructive in application. Byrne, et al., (2002) interested in developing rapid methods to evaluate fish freshness by using general quality indicators and has stated that microbial, chemical, biochemical or other instrumental methods are all appropriate methods for determination of fish freshness, and the analyses must be convenient, fast and inexpensive to perform, and TVB-N levels have been recognized as useful indicators of seafood spoilage. Hebard et al. (1982) discussed the analysis of amines and TVB and their suitability as indices of quality. Howgate, (2010) assumed that the chemical test with the longest history of use as an indicator of freshness is measurement of the amount of basic compounds recovered by distilling fish muscle, or extracts of fish muscle, under alkaline conditions. The amount of these bases is almost invariable expressed on a nitrogen basis. TVB can be determined by distillation methods, a direct water vapour distillation method (Antonocoupoulos, 1968, FAO, 1979, Woyewoda, et al., 1986, Halland and Najaa 1988, Antonocoupoulos and Vyncke, 1989, AOAC 2003, Egyptian Standards, 2006 ) or a water vapour distillation of an acidic extract made with aqueous perchloric or trichloracetic acid (Codex Alimentarius Committee in 1969, Billon et al., 1979, Pearson, 1981, Stockemer and Kruse, 1985, Antonacopoulos and Vyncke 1989, Malle and Poumeyrol 1989 and European Commission 2005). The microdiffusion of an acidic extract (Conway and Byrne, 1933, Conway, 1957 and, 1962, Aksnes, 1989, FAO, 1979) is also used.

The European Commission decision (2005) has specified the analysis methods to be used: a reference procedure involving preliminary deproteination with perchloric acid followed by a water vapour distillation of the acidic extract and three others routine methods that may be used, the microdiffussion method described by Conway and Byrne (1933), the direct distillation method (Antonacopoulos, 1968) and the distillation of an extract deproteinesed by trichloroacetic acid (Codex
Alimentarius Committee on Fish and Fishery Products, 1968).

Hu et al., (1991) illustrated that the amines extraction need a destruction of cellular structures and a protein precipitation by acids. Then, the amines could be recovered into an organic solvent or into a solvent mixture with different polarities. At acid $\mathrm{pH}$, amines are dissolved in the hydrophilic phase. However, at alkaline $\mathrm{pH}$, amines change their polarity. A migration to lipophile phase is observed. An evaporation of organic phase could let a concentration of amines. For these reasons, an extraction with organic solvents and at alkaline $\mathrm{pH}$ will be used to facilitate the concentration and to minimize the wastage (Rosier and Van Peteghem, 1988; Lebiedzinska et al., 1991). Nucleotides In parallel, to the previous methodology, it is necessary to develop a rapid technique to study the degradation of nucleotides. A cellular structure disruption and a protein precipitation with acids are necessary. Perchloric or trichloroacetic acids could be used. Then, neutralization with $\mathrm{NaOH}$ or $\mathrm{KOH}$ is necessary to adjust the $\mathrm{pH}$ between 6.4-7.8. To achieve nucleotides detection, a column of ionic interchange or reverse phase will be used).

\section{Material and Methods}

Twenty samples from each of fresh meat and fresh fish were purchased from local markets in Giza and stored at refrigerator temperature $4 \pm 1^{\circ} \mathrm{C}$ till the beginning of spoilage and examined for determination of TVB-N with 4 different methods at $1^{\text {st }}, 3^{\text {rd }}, 5^{\text {th }}, 7^{\text {th }} \ldots$...day of storage.

\section{DETERMINATION OF TVB-N IN FOOD SAMPLES BY:}

\section{Method 1: Conway's Microdiffusion Method according to FAO, 1979:}

Twenty five grams of sample were homogenated with $75 \mathrm{ml}$ distilled water and the $\mathrm{pH}$ was brought to 5.2 with $2 \mathrm{M}$ HCL then heated slowly to $70 \mathrm{C}^{\circ}$ and cooled at room temperature, the mixture was filtered. Two $\mathrm{ml}$ $0.01 \mathrm{M}$ HCL were added into the center compartment of the Conway dish, $2 \mathrm{ml}$ of the 
filtrate were added into the outer compartment with $1 \mathrm{ml}$ of saturated potassium carbonate. The dish was covered with a glass plate and left at $37 \mathrm{C}^{\circ}$ for 2 hours. The HCL was titrated with $0.01 \mathrm{~N} \mathrm{NaOH}$ using $2-3$ drops of methyl red indicator.

\section{Calculation}

Mg TVB-N/100g sample $=0.01 \times(2-\mathrm{t}) \times 96 \times$ $14 \times 100 / 25 \times 2=26.88(2-\mathrm{t})$

$\mathrm{t}=$ volume of $\mathrm{NaOH}$ used in titration.

96 is taken to be the amount of water (in ml) in which the sample weight was dispersed, assuming that the $25 \mathrm{~g}$ of chopped fish contained $4 \mathrm{~g}$ of dry matter.

Method 2: Direct water vapor distillation method according to Egyptian Standards, ES 2760-1 and 63-9/ 2006:

Ten $\mathrm{g}$ of sample were weighed with $0.01 \mathrm{~g}$ accuracy and straight into the distillation bottle, $2 \mathrm{~g}$ of $\mathrm{MgO}$ (magnesium oxide) were added and $300 \mathrm{ml}$ of distilled water (the water was added in small portions to avoid lumps of fish).

Distillation flask was arranged in the distillation apparatus. A collection flask with $25 \mathrm{ml}$ of Boric acid 2\% was placed under the tube from the cooling coil. Take care that the end of the tube was immersed in the boric acid. Distillation was started and continues for $15 \mathrm{~min}$.

\section{Titration}

The contents of the collection flask were titrated from green to grey with $0.1 \mathrm{~N} \mathrm{H}_{2} \mathrm{SO}_{4}$.

\section{Calculations}

TVB-N mg N/100g $=(\mathrm{ml} \times \mathrm{N} \times 14.01) / \mathrm{g} \times 100$

$\mathrm{ml}=\mathrm{ml}$ of $\mathrm{H}_{2} \mathrm{SO}_{4}$ titrated

$\mathrm{N}=$ strength of $\mathrm{H}_{2} \mathrm{SO}_{4}$

$\mathrm{g}=$ weight of sample $(10 \mathrm{~g})$

14.01 molecular weight of Nitrogen
Method 3: water vapor distillation of an acidic extract (Perchloric acid 6\%) according to European Commission (2005):

The sample to be analyzed was ground carefully by a meat grinder. Exactly $10 \mathrm{~g} \pm$ $0,1 \mathrm{~g}$ of the ground sample were weighed in a suitable container, mixed with $90 \mathrm{ml}$ perchloric acid solution $6 \%$, homogenized for two minutes with a blender and then filtered. Steam distillation of $50 \mathrm{ml}$ of the extract after sufficient alkalinization with $\mathrm{NaOH} 20 \%$ (6.5 $\mathrm{ml}$ ) and addition of several drops of phenolphthalein $(1 \mathrm{~g} / 100 \mathrm{ml} 95 \%$ ethanol) and a few drops silicone anti foaming agent began immediately. The steam distillation was regulated so that around $100 \mathrm{ml}$ of distillate were produced within 10 minutes. The distillation outflow tube was submerged in a receiver with $100 \mathrm{ml}$ boric acid solution $3 \%$ to which three to five drops of the indicator solution, Tashiro Mixed Indicator (2 g Methyl - red and $1 \mathrm{~g}$ Methylene - blue are dissolved in $1000 \mathrm{ml} 95 \%$ ethanol) have been added. After exactly 10 minutes the distillation was ended. The volatile bases contained in the receiver solution were determined by titration with standard hydrochloric solution $0.01 \mathrm{M}$ till the $\mathrm{pH} 5.0 \pm 0.1$

\section{Calculation:}

TVB-N $(\mathrm{mg} / 100 \mathrm{~g}$ sample $)=(\mathrm{V} 1-\mathrm{V} 0) \times 0.14$ $\times 2 \times 100 / \mathrm{M}$

$\mathrm{V} 1=$ Volume of $0.01 \mathrm{M}$ hydrochloric acid solution in $\mathrm{ml}$ for sample;

$\mathrm{V} 0=$ Volume of $0.01 \mathrm{M}$ HCL solution in $\mathrm{ml}$ for blank; $\mathrm{M}=$ Weight of sample in $\mathrm{g}$.

Blank: Instead of the extract, $50 \mathrm{ml}$ perchloric acid solution $6 \%$ was used.

Method 4: water vapour distillation of an acidic extract (trichloroacetic acid $\mathbf{7 . 5 \%}$ ) according to Malle and Poumeyrol (1989):

Briefly, $200 \mathrm{ml}$ of a $7.5 \%$ aqueous trichloroacetic acid solution were added to 100 $\mathrm{g}$ of fish muscle and homogenized in a blender. The mixture was filtered through Whatman filter paper. Steam distillation of 25 $\mathrm{ml}$ of filtrate was performed using a Kjeldahltype distillator with addition of $6 \mathrm{ml}$ of $10 \%$ 
$\mathrm{NaOH}$. A beaker containing $10 \mathrm{ml}$ of $4 \%$ boric acid and $0.04 \mathrm{ml}$ of methyl red and bromocresol green indicator was placed under the condenser for the titration of ammonia. Distillation was started and steam distillation continued until a final volume of $50 \mathrm{ml}$ was obtained in the beaker ( $40 \mathrm{ml}$ of distillate). The boric acid solution turned green when alkalinised by the distilled TVB-N which was titrated with aqueous $0.0125 \mathrm{M}$ sulphuric acid solution using a $0.05 \mathrm{ml}$ graduated burette.
Complete neutralization was obtained when the colour turned pink on the addition of a further drop of sulphuric acid. The TVB-N content was calculated by the following equation:

TVB-N mg/100g $=14 \mathrm{mg} / \mathrm{mol} \times \mathrm{a} \times \mathrm{b} \times 2 \times$ $300 / 25 \mathrm{ml}$

Where: $\mathrm{a}=\mathrm{ml}$ of sulphuric acid. $\mathrm{b}=$ molarity of sulphuric acid.

\section{Results and Discussion}

Table (1): Mean values of TVB-N (mg/100g) of meat and fish with four different methods of determination during storage in refrigerator $(n=20)$ :

\begin{tabular}{|c|c|c|c|c|c|c|c|c|}
\hline \multirow{2}{*}{$\begin{array}{c}\text { Day of } \\
\text { storage }\end{array}$} & \multicolumn{2}{|c|}{ Method 1 } & \multicolumn{2}{c|}{ Method 2 } & \multicolumn{2}{c|}{ Method 3 } & \multicolumn{2}{c|}{ Method 4 } \\
\cline { 2 - 9 } & Meat & Fish & Meat & Fish & Meat & Fish & Meat & Fish \\
\hline $\mathbf{1}^{\text {st }}$ & $4.03 \pm 0.152$ & $5.03 \pm 1.12$ & $6.72 \pm 0.37$ & $7.71 \pm 0.58$ & $6.18 \pm 4.59$ & $7.14 \pm 0.47$ & $6.62 \pm 0.7$ & $6.42 \pm 0.43$ \\
\hline $\mathbf{3}^{\text {rd }}$ & $8.06 \pm 0.1$ & $5.376 \pm 0.21$ & $10.5 \pm 0.48$ & $9.06 \pm 0.34$ & $9.15 \pm 1.48$ & $8.4 \pm 0.73$ & $9 \pm 0.37$ & $8.4 \pm 0.33$ \\
\hline $\mathbf{5}^{\text {th }}$ & $11.47 \pm 0.32$ & $9.74 \pm 0.08$ & $14 \pm 0.06$ & $13.3 \pm 0.07$ & $12.2 \pm 1.05$ & $10.4 \pm 0.86$ & $12.6 \pm 0.77$ & $10.64 \pm 0.63$ \\
\hline $7^{\text {th }}$ & $20.16 \pm 0.09$ & $20.16 \pm 0.33$ & $23.4 \pm 0.61$ & $23.52 \pm 0.04$ & $19.82 \pm 1.34$ & $21.53 \pm 0.9$ & $19.76 \pm 0.54$ & $22.3 \pm 0.92$ \\
\hline $\mathbf{9}^{\text {th }}$ & $33.6 \pm 0.5$ & $33.1 \pm 0.29$ & $36.29 \pm 0.07$ & $37.6 \pm 0.1$ & $33.9 \pm 0.32$ & $34.8 \pm 1.05$ & $34.4 \pm 0.42$ & $35 \pm 0.81$ \\
\hline $\mathbf{1 1}^{\text {th }}$ & $43 \pm 0.31$ & $66.5 \pm 0.39$ & $50.08 \pm 0.5$ & $73 \pm 0.1$ & $47.1 \pm 0.32$ & $70.67 \pm 1.48$ & $47.8 \pm 0.33$ & $70.2 \pm 1.04$ \\
\hline
\end{tabular}

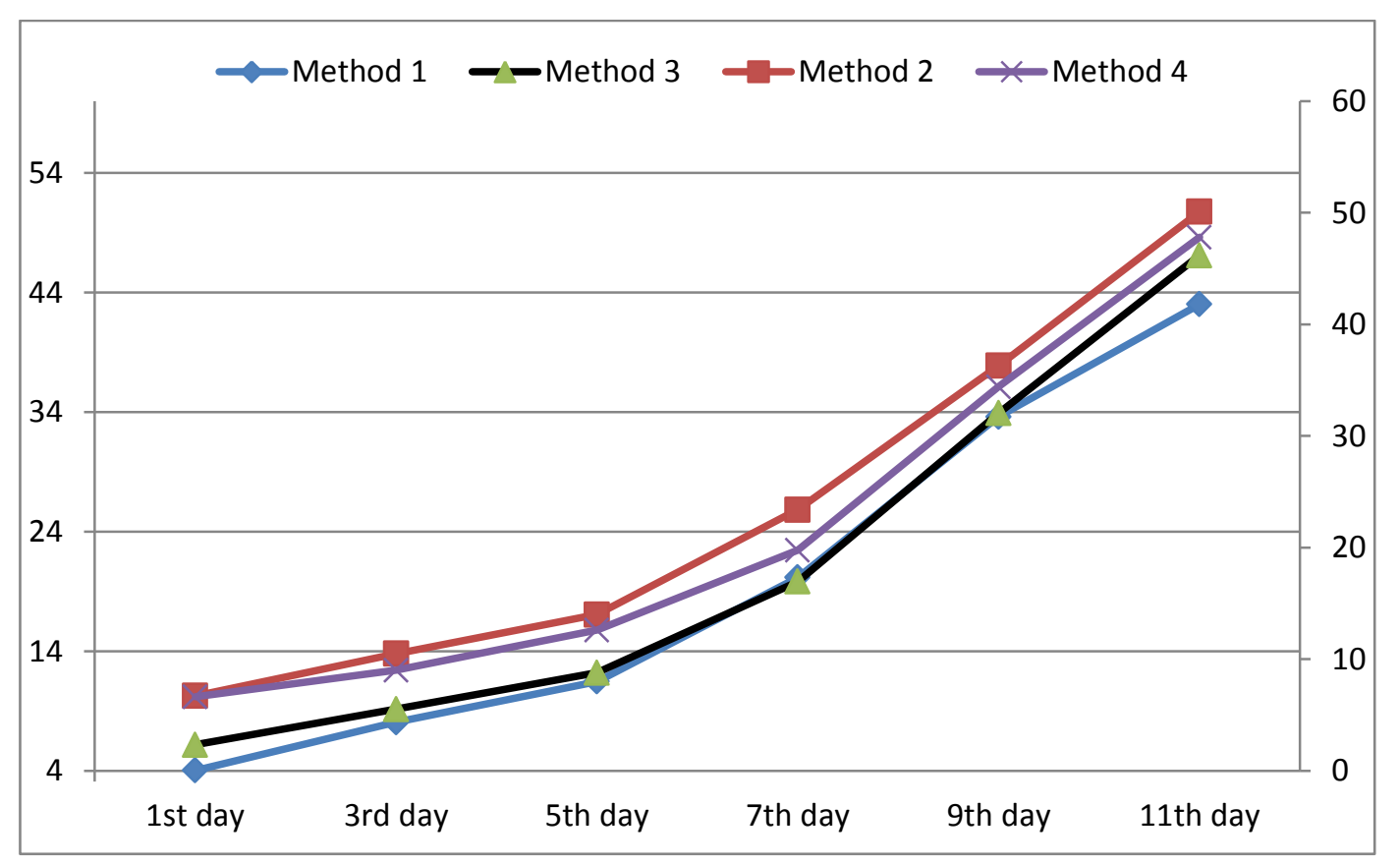

Fig. (1): Mean values of TVB-N in $\mathrm{mg} / 100 \mathrm{~g}$ of meat with four deferent methods of determination during storage in refrigerator. 


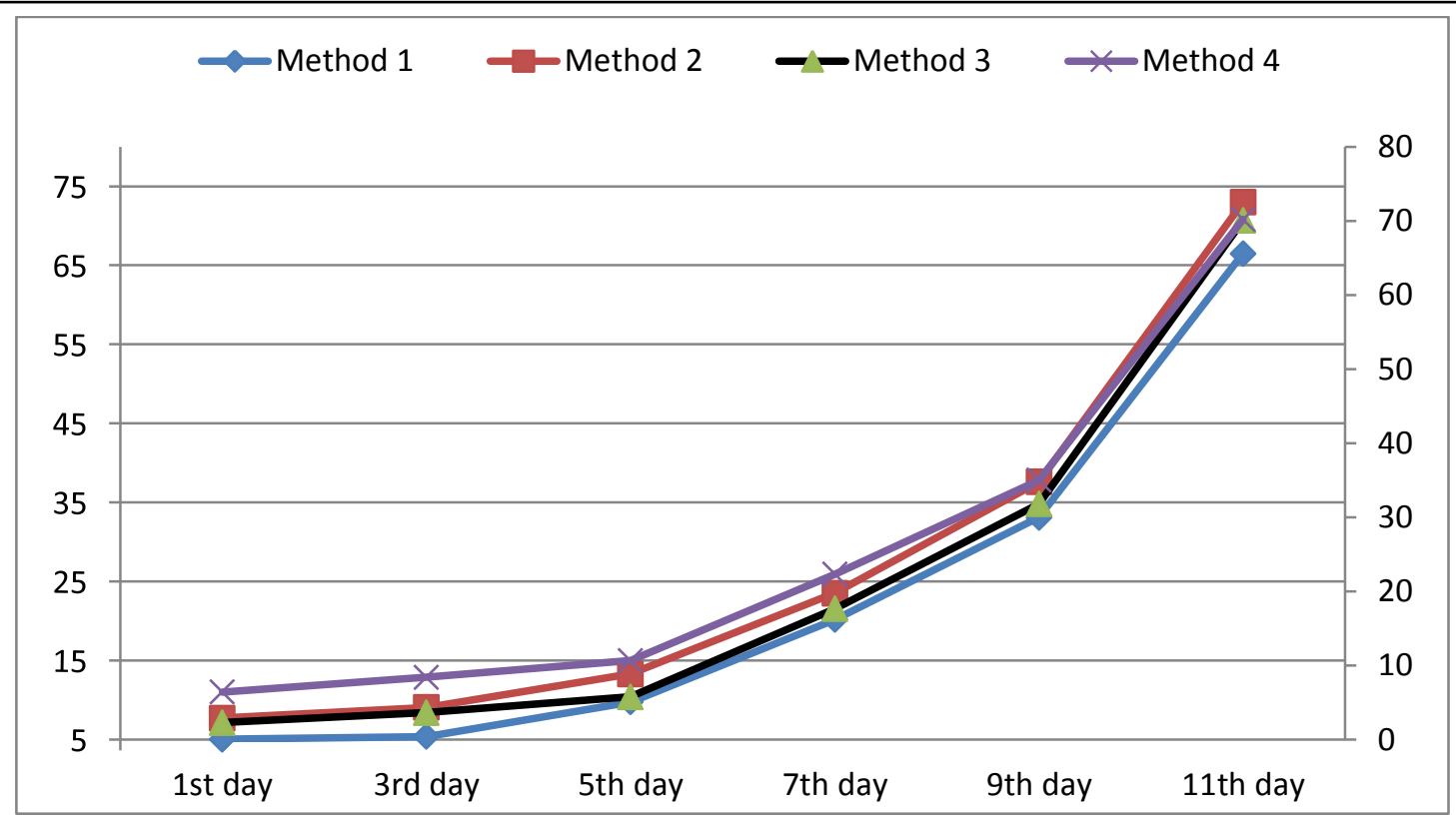

Fig. (2): Mean values of TVB-N in $\mathrm{mg} / 100 \mathrm{~g}$ of fish with four different methods of determination during storage in refrigerator.

By comparing the results of Conway's Microdiffusion; Direct water vapor distillation with $\mathrm{MgO}$; water vapour distillation of an acidic extract using Perchloric acid 6\% and vapour distillation of an acidic extract using trichloroacetic acid $7.5 \%$ methods used for freshness evaluation of meat and fish kept at $4^{\circ} \mathrm{C} \pm 1$, (table 1, fig. 1 and fig. 2) it was observed that the mean values of TVB-N $\mathrm{mg} / 100 \mathrm{~g}$ of fresh meat samples at $1^{\text {st }}$ day were $4.03 \pm 0.152, \quad 6.72 \pm 0.37, \quad 6.18 \pm 4.59$ and $6.62 \pm 0.7$ respectively and the mean values of TVB-N mg/100g of fresh fish were $5.03 \pm 1.12$, $7.71 \pm 0.58, \quad 7.14 \pm 0.47$ and $6.42 \pm 0.43$ respectively, these values increased gradually till spoilage occurred reach to $43 \pm 0.31$, $50.08 \pm 0.5,47.1 \pm 0.32$ and $47.8 \pm 0.33$ for fresh meat and $66.5 \pm 0.39,73 \pm 0.1,70.67 \pm 1.48$ and $70.2 \pm 1.04$ for fresh fish respectively on $11^{\text {th }}$ day, so the TVB-N contents increased with increasing storage time and the all four methods were showed some deviations (Figures 1 and 2) also direct water vapor distillation with $\mathrm{MgO}$ method presented relatively higher results than other methods $(6.72 \pm 0.37$ and $7.71 \pm 0.58 \mathrm{mg} / 100 \mathrm{~g}$ of fresh meat and fresh fish samples respectively) but Conway Microdiffusion method produce the lowest results $(4.03 \pm 0.152$ and $5.03 \pm 1.12$ $\mathrm{mg} / 100 \mathrm{~g}$ of fresh meat and fresh fish samples respectively) at first day of storage. Homogenization of samples with trichloroacetic acid produces jelly like fluid which is difficult to be filtered and may need centrifugation. Cann (1974) have found the increase in TVB-N to be low during the initial period of storage, with a rapid increase noted afterwards. Connell (1975) stated that TVBN content in shrimp has highly positive and highly negative correlation with storage time indicating that TVB-N is a good indicator of spoilage. . Boee et al. (1982) working on the storage of shrimp and has observed that TVB$\mathrm{N}$ increased evenly. Matches (1982) working on shrimp stored at 5 different temperature, found that TVB-N increased both with increase in time and temperature. Clancy et al. 1995 reported that the TVN level increased during storage as monitored by all methods, especially after $8-9$ days. The values after 15 days of storage ranged from 80 to $114 \mathrm{mg}$ $\mathrm{N} / 100 \mathrm{~g}$ fish depending upon the method employed. Etienne, (2005) found that The TVB-N content increased slightly during the first days of storage, this slight increase may reflect the amines production by autolytic processes. Nevertheless in some experiments on small fishes as plaice or whiting during the 
first week of iced storage a decrease of TVB-N content has been observed, the some volatile amines, mainly ammonia, were leached out by the melting ice (Oehlenschläger, 1997 b). After the early days of iced storage, the TVB$\mathrm{N}$ content increases with a larger scattering of the values mostly produced by spoilage bacteria. TVB analyses reflect only stages of advanced spoilage of fish, they are considered unreliable for the evaluation of the fish freshness in the early stage of storage and they don't reflect the mode of spoilage, bacterial or autolytic (Oehlenschläger, 1992, 1997a, b, ; Nunes et al., 1992, ; Huss, 1995 and BaixasNogueras et al. 2002). TVB is considered as useful parameter although it does not fully satisfy sanitarians and is therefore subjected to certain valid criticisms (Malle and Poumeyrol, 1989). Gao, (2007) aimed to analyzed the influences of different precooling methods, i.e. slurry ice (group B), $\mathrm{CBC}$, (group C) (combined blast and contact freezing) and usage of cooling mats (group D), on the quality of fresh cod fillets during further storage at $-1.5{ }^{\circ} \mathrm{C}$ and found that the comparison of TVN as a quality parameters of fresh cod showed that there was a good correlations with the evaluation of the quality of fresh cod. An increase in TVN was obtained throughout storage time in the four groups but there was not much difference in TVN observed at first 6 day in all groups. The formation of TVN was delayed during the 10 days of storage in groups B, C and D compared to group $\mathrm{E}$. The highest TVN values were measured after $10^{\text {th }}$ day of storage. Liu et al., (2011) mentioned that the TVB-N content in meat samples was an important indicator for estimating meat freshness. During the storage, the changes of TVB-N content in four kinds of meat samples were increased and the samples stored for less than 7 days in decompression room. After 10 days, the rapid increase of TVB-N content suggested that the quality of all samples depressed significantly.

Martin, (1979) described the determination of volatile amines by distillation of the sample with magnesium oxide using kjeldahl macrodistillation unit and Conway's diffusion cell and by semi-micro kjeldahl distillation apparatus using trichloracetic acid. Botta et al., (1984) reported that the microdiffusion method with its low cost, simplicity and speed of use without loss of precision was the method of choice for TVN measurement, and found poor agreement among six published TVB procedures. Most depend upon either steam distillation of volatile amines or microdiffusion of an extract (Conway, 1962); the latter method is the most popular in Japan. Clancy et al. (1995) analyzed herring for total volatile nitrogen (TVN) by each of four methods included microdiffusion with $\mathrm{K}_{2} \mathrm{CO}_{3}$ or $\mathrm{KOH}$, steam distillation with $\mathrm{NaOH}$, and with direct distillation with $\mathrm{MgO}$ and found a high correlation between methods (0.985 0.994) and the direct distillation with $\mathrm{MgO}$ gave consistently higher values than other three methods, these may have occurred as a result of protein breakdown during atmospheric distillation (Pearson and Muslemuddin, 1968 ; 1969 ; Botta et al., 1984). Huss, (1995) said that although TVB analyses are relatively simple to perform, they generally reflect only later stages of advanced spoilage and results depend to a great extent on the method of analysis. Riquixo, (1998) investigated the suitable chemical methods for seafood products with respect to their accuracy and suitability for determination of freshness of fish in Mozambique. and found a good correlation between $\mathrm{MgO}$ and TCA-extract steam distillation methods for TVB determination also reported that the level of TVBN for white fish is generally considered to be fresh if the TVB is less $20 \mathrm{mg} \mathrm{N} / 100 \mathrm{~g}$ sample. If the TVB reaches $30 \mathrm{mg} \mathrm{N} / 100 \mathrm{~g}$ most authorities consider the fish to be stale, whilst at level of $40 \mathrm{mg} \mathrm{N} / 100 \mathrm{~g}$ the fish is regarded as unfit for consumption. Erkan,(2005) determined the total volatile basic nitrogen (TVB-N) using 6\% perchloric acid and the results were expressed as $\mathrm{mg}$ TVB-N per $100 \mathrm{~g}$ of wet sample. 
Nitrogen Recovery Verification:

Quality control analysis was performed and analysis of standards with each procedure. The standards available from Sigma Aldrich Co., the ammonium sulfate serve as a check on distillation efficiency and accuracy in titration steps. Run nitrogen recoveries to check accuracy of each procedure and equipment using $1 \mathrm{~g}$ ammonium sulfate dissolved in $100 \mathrm{ml}$ distilled water, $(100 \mathrm{ml}$ of water contain
$210.9 \mathrm{mg}$ nitrogen) (Thiex and Manson, 2002) and Riquixo, (1998) all other reagents were added as stated in test portion preparation for each method.

$\%$ Recovery $=$ Actual $\%$ Nitrogen $\times 100 / 210.9$

This experiment repeated 12 times, and the average was taken.

Table (2): Nitrogen Recovery Verification $(n=12)$ :

\begin{tabular}{|c|c|c|c|c|}
\hline & Method 1 & Method 2 & Method 3 & Method 4 \\
\hline $\begin{array}{c}\text { Mean mg nitrogen } \\
\text { recovered }\end{array}$ & $136.74 \pm 1.33$ & $142.2 \pm 1.08$ & $210.5 \pm 0.36$ & $212.44 \pm 2.6$ \\
\hline Accuracy \% & 64.84 & 69.43 & 99.81 & 100.73 \\
\hline
\end{tabular}

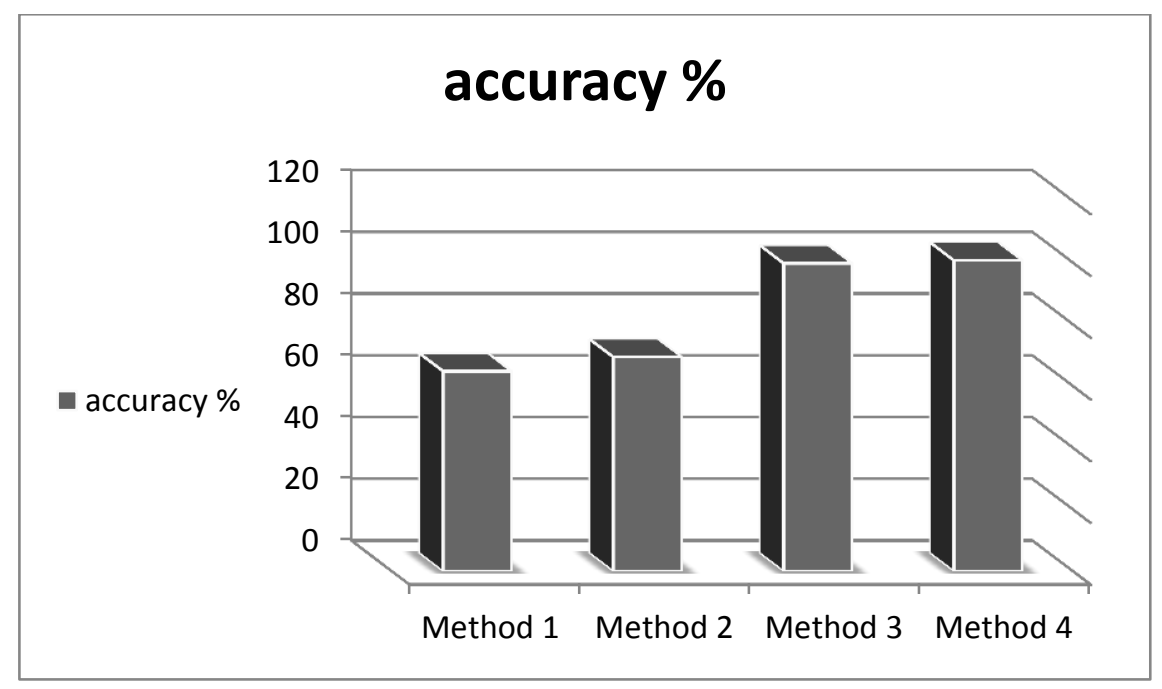

Fig (3): Nitrogen Recovery Verification:

Table (2) and Fig (3) show the amount of nitrogen in $\mathrm{mg} / 100 \mathrm{~g}$ detected from $100 \mathrm{ml}$ standard solution contained $210.9 \mathrm{mg}$ nitrogen using four different methods (Conway Microdiffusion; Direct water vapor distillation with $\mathrm{MgO}$; water vapour distillation of an acidic extract using Perchloric acid 6\% and vapour distillation of an acidic extract using trichloroacetic acid $7.5 \%$ methods) were $136.74 \pm 1.33, \quad 142.2 \pm 1.08, \quad 210.5 \pm 0.36$ and $212.44 \pm 2.6$ which produce $64.84,69.43$, 99.81 and 100.73 recovery and accuracy \% respectively, where accuracy is the closeness of the obtained standards to the true value and is usually stated in terms of recovery. Riquixo, (1998), European Commission (2005), Erkan, (2005)

\section{CONCLUSION}

In the comparison of four methods (Conway Microdiffusion; Direct water vapor distillation with $\mathrm{MgO}$; water vapour distillation of an acidic extract using Perchloric acid 6\% and vapour distillation of an acidic extract using trichloroacetic acid $7.5 \%$ methods), it was found that all methods were sensitive need an experience personnel. Water vapour distillation of an acidic extract using 
Perchloric acid $6 \%$ is the quickest of the methods but using Perchloric acid need some precaution and application of chemical safety roles and the European Union reported that the reference method to be used for checking the TVB-N limit is the method involving distillation of an extract deproteinized by perchloric acid.

\section{References}

Aksnes, A. (1989): Effect of proteinase inhibitors from potato on the quality of stored herring. J. Sci. Food Agric., 49: $225-234$.

Ali, M.Y.; Sharif, M.D. I.; Adhikari, R.K. and Faruque, O. (2010): Post mortem variation in Total Volatile Base Nitrogen and Trimethylamine Nitrogen between Galda (Macrobrachium rosenbergii) and Bagda (Penaeus monodon). Univ.j. Zool. Raishahi. Univ. 28: $07-10$.

Antonocoupoulos, N. and Vyncke, W. (1989): Determination of volatile basic nitrogen in fish. Z. Lebensm Unters Forsch., 189:309-316

Antonocoupoulos, N., (1968): Handbuch der Lebensmittelchemie, vol 111/2. Springer Verlag, Berlin.

Association of Official Analytical Chemistry AOAC (2003): Official Methods of Analysis of AOAC International, 18th ed., , Suite 500, 481 North Frederick Avenue, Gaithersburg, Maryland,USA.

Baixas-Nogueras, S.; Bover-Cid, S.; Veciana-Nogues, T. and Vidal-Carou, M.C. (2002): Chemical and sensory changes in Mediterranean hake (Merluccius merluccius) under refrigeration $\left(6-8^{\circ} \mathrm{C}\right)$ and stored in ice. Journal of Agricultural and Food Chemistry, 50 (22): 6504-6510.

Billon, J., Ollieuz, N. and Tao, S.H. (1979): Etude d'une nouvelle méthode de dosage de l'azote basique volatil total pour l'évaluation qualitative des produits de la pêche. Revue Technique
Vétérinaire de L'Alimentation, 149: 1317.

Boee, B.; Losnegrad, N. and Xu, X. L. (1982): Determination of indole as a freshness assessment of shrimp. Fiskeridir Skr., 2(2): 35-38.

Botta, J.R. ; Lauder, T. and Jewer, M.A. (1984): Effect of methodology on total volatile basic nitrogen (TVB-N) determination as an index of quality of fresh Atlantic cod (Gadus morhua). J. Food Sci. 49: 734 - 750.

Byrne, L. ; Lau, K.T. and Diamond, D. (2002): Monitoring of headspace total volatile basic nitrogen from selected fish species using reflectance spectroscopic measurements of $\mathrm{pH}$ sensitive films. Analyst, 127: 1338-1341.

Cann, D.C. (1974): Bacteriological aspects of tropical shrimp. In: Kreuzer, R.. (ed.) Fishery Products, West Byfleet, Fishery News. pp. 338-344.

Chan, S. T.; Yao, M.W.Y.; Wong, Y. C.; Wong, T.; Mok, C. S and Sin, D. W. M. (2006): Evaluation of chemical indicators for monitoring freshness of food and determination of volatile amines in fish by headspace solid-phase microextraction and gas chromatography-mass spectrometry. Eur. Food Res. Technol., 224: 67-74.

Chebet Lillian, B.A.C. (2007): Alternative methods for fish grading. Fisheries Training Institute, P.O. Box, 124 Entebbe, Uganda.

Clancy, G.S.; Beames, R.M.; Higgs, D.A. and Dosanjh, B.S. (1995): Effect of methodology on the determination of total volatile nitrogen and trimethylamine levels in previously frozen pacific herring (Clupea harengus pallasi) stored at $2-5 \mathrm{C}^{\circ}$ for up to 15 days. Can. Tech. Rep. Fish Aquat. Sci., 2047: 10 .

Codex Committee on Fish and Fishery Products, 3rd session, (1968): FAO/WHO Method for the determination of total volatile basic 
nitrogen (TVB) in fish muscle. Bergen, 7-11 October, as Codex Fish 1/7, 9 p.

Codex Committee on Food Hygiene, $6^{\text {th }}$ session, (1969): FAO/WHO, Washington, D.C. 5-6 May.

Connell, J.J. (1975): Control of Fish Quality. Fishing New Books Ltd. London, pp.127-129.

Conway, E. J. (1957): Microdiffusion analysis and volumetric error. Crosby Lockwood and Son Ltd. , London.

Conway, E.J. and Byrne, A. ( 1933): An absorption apparatus for the microdetermination of certain volatile substances. I. The micro-determination of ammonia. Biochemical Journal, 27: 419-429.

Conway, W.J. (1962): Microdiffusion analysis and volumetric error. Crosby Lockwood, London.

Egyptian Standard, ES: 2760-1/ (2006): Physical and chemical methods for testing fish and fishery products part : 1 , frozen fish. Arab Republic of Egypt, Egyptian Organization for Standardization and Quality.

Egyptian Standard, ES: 63- 9/ (2006): Method of analysis and testing for meat and meat products. Arab republic of Egypt, Egyptian Organization for Standardization and Quality.

Erkan, N. (2005): Changes in quality characteristics during cold storage of shucked mussels (Mytilus galloprovincialis) and selected chemical decomposition indicators. Journal of the Science of Food and Agriculture, 85:2625-2630.

Etienne, M. (2005): Volatile amines as criteria for chemical quality assessment. SeaFoodPlus experts, France.

European Commission Regulation (EC) No 2074/2005 of 5 December 2005 total volatile basic nitrogen (TVB-N) limit values for certain categories of fishery products and analysis methods to be used Official Journal of the European Union pp. $36-39$.

FAO (1979): Manual of Food Quality Control : 3 Commodities. Food and Agriculture Organization of the United Nations, Rome.

Foegeding, F.; Cassidy, P. and Horner, W. (1996): Characteristics of Edible Muscle Tissue. In: Food Chemistry (3rd Edition). (Fenemma, O.R. ed.) pp. 45-47

Gao, H.Y. (2007): methods of pre-cooling for fresh cod (gadus morhua) and influences on quality during chilled storage at $-1.5^{\circ} \mathrm{c}$. UNU - Fisheries Training Programme $1-47$.

Halland, H. and Najaa, L.R. (1988): Ammonia (NH3) and total volatile nitrogen (TVN) in preserved and unpreserved stored whole fish. J. Sci. Food Agric.,44: 335 - 342.

Hebard, C.E., Flick, G.J. and Martin, R.E. (1982): Occurrence and significance of trimethylamine oxide its derivatives in fish and shellfish. In: Chemistry and Biochemistry of Marine Food Products. Pp 149-304. R.E. Martin, G.J. Flick, C.E. Hebard, and D.R. Ward eds. Avi Publishing Co., Inc., Westport, Co.

Howgate, P. (2010): A critical review of total volatile bases and trimethylamine as indices of freshness of fish. Part 1. Determination. EJEAFChe., 9: (1) 2957.

Hu, W.; Haraguchi, H. and Takeuchi, T. (1991): Analysis of nucleotides by High-Performance Liquid Chromatography with phosphorousselective detection. J. Chromat., 557:441-449.

Huss, H.H. (1995): Quality and quality changes in fresh fish. FAO Fisheries Technical Paper 348. P. 53. Food and Agriculture Organization, Rome, Italy. 
Jones, N.R. (1954): Spoilage of Some Marine Fish from California Beach J. Fish Res. Bd. Can., 4: 54, XI, VII.

Lebiedzinska, A.; Lamparczyk, H.; Ganowiak, Z. and Eller, K.L. (1991): Differences in biogenic amines patterns in fish obtained from commercial sources. Z. Leben. U. Forsh., 192:240243.

Liu, J.; Guan, X.; Shen, Y. and Zhang, P. (2011): Identification of Meat Freshness Based on Particle Swarm Optimization and Support Vector Machine, 2nd International Conference on Biotechnology and Food Science, IPCBEE, (7): IACSIT Press, Singapore.

Malle, P. and Poumeyrol, M. (1989): A new chemical criterion for the quality control of fish: trimethylamine/total volatile basic nitrogen (\%). J. Food Prot., 52:419-423.

Martin, P.G. (1979): Manuals of food quality control.3Commodities. Food and Agriculture Organization of the United Nations, Rome 1979.

Matches, J.R. (1982): Microbial changes in packages. In: Martin, R. (ed.), Proceeding of the First National Conference on Seafood Packaging and Shipping, National Fisheries Inst. Seattle, WA, pp. 46-70.

Nunes M.L.; Batista I. and Morao de Campos R. (1992): Physical, chemical and sensory analysis of Sardine (Sardina pilchardus) stored in ice. Journal of the Science of Food and Agriculture, (59), 37-43

Oehlenschläger, J. (1997 b.): Suitability of ammonia-N, dimethylamine-N, trimethylamine- $\mathrm{N}$, trimethylamine oxide- $\mathrm{N}$ and total volatile basic nitrogen as freshness indicators in seafoods. "Methods to determine the freshness of fish in research and industry. Evaluation of Fish Freshness", Institut International du Froid, 92-99

Oehlenschläger, J. (1992): Evaluation of some well established and some underrated indices for the determination of freshness and / or spoilage of ice stored wet fish. Proceedings of the International Conference "Quality assurance in the fish industry", 339-345 Huss H.H. et Al. (Eds), Elsevier Science Publishers,

Oehlenschläger, J. (1997 a.): Volatile amines as freshness/spoilage indicators. A literature review. In: Seafood from Producer to Consumer, Integrated Approach to Quality. Proceedings of the International Seafood Conference, EdJ.B. Luten, T. Borrensen., J. Oehlenschläger, Elsevier Developments in Food Science, $n^{\circ} 38$, 571-586

Pearson, D. and Muslemuddin, M. (1968): The accurate determination of total volatile nitrogen in meat and fish. 1. Techniques and application to beef and salmon. J. Assoc. Public Analysts., 6: $117-123$.

Pearson, D. and Muslemuddin, M. (1969): The accurate determination of total volatile nitrogen in meat and fish. 2. Application to white teleostean fish. J. Assoc. Public Analysts, 7: 50 - 54.

Pearson, D.(1981): The Chemical analysis of Foods, 8th ed. Churchill Livingstone, Edinburgh, London Melbourne and New York.

Riquixo, C. (1998): Evaluation of suitable chemical methods for seafood products in Mozambique. UNU-Fisheries Training Programme, $1-58$.

Rosier, J. and Van Peteghem, C.V. (1988): A screening method for the simultaneous determination of putrescine, cadaverine, histamine, spermidine and spermine in fish by means of High-Pressure Liquid Chromatography of their 5dimethylaminonaphtalene-1-sulphonil derivatives. Z. Lebensm. U. Forsh., 186:25-28. 
Shewan, J.M. (1976): The bacteriology of fresh and spoiling fish and biochemical changes induced by bacterial action. In: Proc. of the Conf. on the handling, processing and marketing of tropical fish. London, Tropical Products Institute, pp. 377-94.

Stansby, M.E.; Harrison, R.W.; Dassow, J. and Sater, M. (1944): Spoilage of Tropical Fish and Product Development. (Reilly, A. ed.) Food and Agricultural Organization of the United Nations (Rome). p.122.

Stockemer, J. and Kruse, R. (1985): Neue Methoden zur Bestimmung von TVB-N bzw. TMA-N in Fischen und Fischerzeugnissen. Archiv für Lebensmittelhygiene, 36 116-117

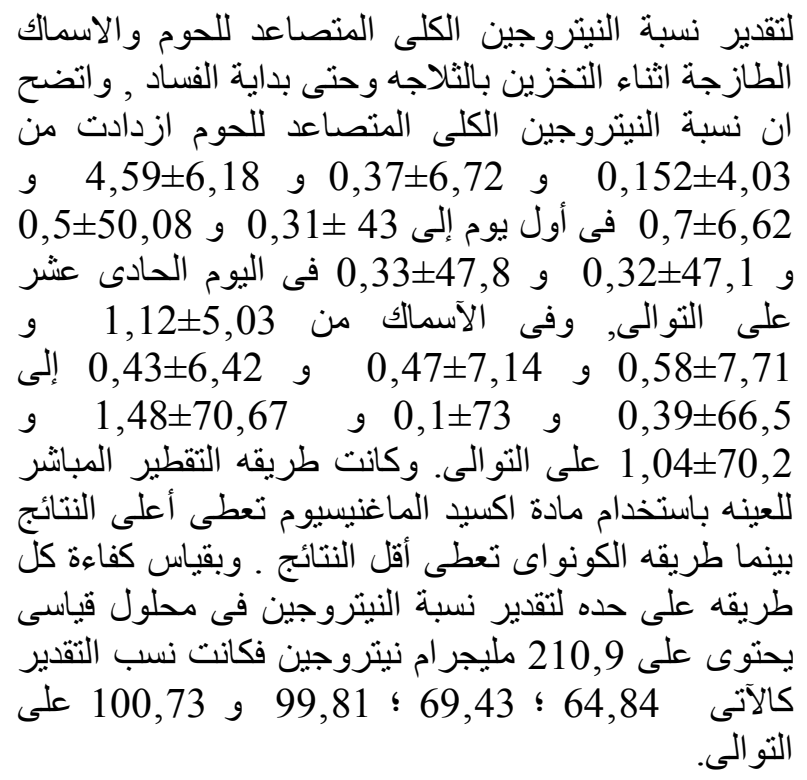

Thiex, N. J. and Manson, H. (2002): Determination of crude protein in animal feed, forage, grain, and oilseeds by block digestion with a copper catalyst and steam distillation into boric acid: Collaborative Study. J. of AOAC International, 85 (2): $309-317$.

Woyewoda, A.D.; Shaw, S.J.; Ke, P.J. and Burns, B.G. (1986): Recommended laboratory methods for the assessment of fish quality. Can. Tech. Rep. Fish. Aquat. Sci., 1448: 143.

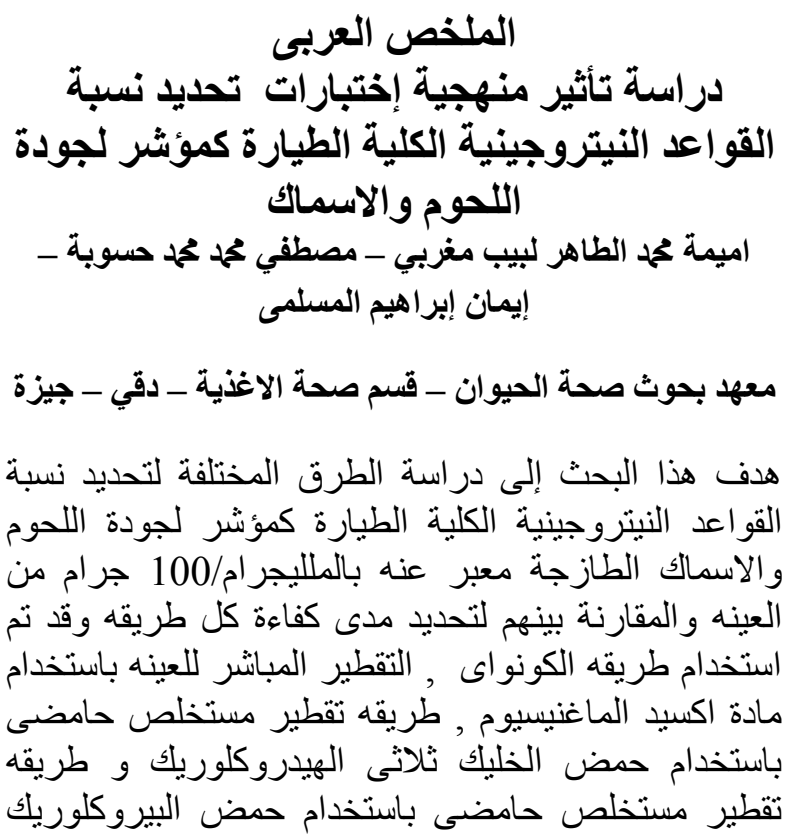

